Article

\title{
Experimental Study of Montmorillonite Structure and Transformation of Its Properties under Treatment with Inorganic Acid Solutions
}

\author{
Victoria V. Krupskaya ${ }^{1,2, *}$, Sergey V. Zakusin ${ }^{1,2}$, Ekaterina A. Tyupina ${ }^{3,4}$, Olga V. Dorzhieva ${ }^{1,5}$, \\ Anatoliy P. Zhukhlistov ${ }^{1}$, Petr E. Belousov ${ }^{1}$ and Maria N. Timofeeva ${ }^{6}$ \\ 1 Belov Laboratory of Mineral Cristallochemistry, Institute of Ore Deposits, Petrography, Mineralogy and \\ Geochemistry, Russian Academy of Science, Moscow 119017, Russia; zakusinsergey@gmail.com (S.V.Z.); \\ dorzhievaov@gmail.com (O.V.D.); anzhu@igem.ru (A.P.Z.); pitbl@mail.ru (P.E.B.) \\ 2 Department of Ecological Geology, Faculty of Geology, Lomonosov Moscow State University, \\ Moscow 119899, Russia \\ 3 Institute of Modern Energetics and Nanotechnology Materials-IPC, Dmitry Mendeleev University of \\ Chemical Technology of Russia, Moscow 125480, Russia; tk1972@mail.ru \\ 4 National Research Nuclear University, Moscow 115409, Russia \\ 5 Laboratory of Physical Methods Application to the Study of Rock-forming Minerals, Geological Institute, \\ Russian Academy of Sciences, Moscow 119017, Russia \\ 6 Research Group for Heterogeneous Catalysts for Liquid-Phase Selective Oxidations, Boreskov Institute of \\ Catalysis SB RAS, Novosibirsk 630090, Russia; timofeeva@catalysis.ru \\ * Correspondence: krupskaya@ruclay.com; Tel.: +7-499-230-82-96
}

Academic Editor: Annalisa Martucci

Received: 17 December 2016; Accepted: 19 March 2017; Published: 23 March 2017

\begin{abstract}
This paper discusses the mechanism of montmorillonite structural alteration and modification of bentonites' properties (based on samples from clay deposits Taganskoye, Kazakhstan and Mukhortala, Buriatia) under thermochemical treatment (treatment with inorganic acid solutions at different temperatures, concentrations and reaction times). Treatment conditions were chosen according to those accepted in chemical industry for obtaining acid modified clays as catalysts or sorbents. Also, more intense treatment was carried out to simulate possible influence at the liquid radioactive site repositories. A series of methods was used: XRD, FTIR, ICP-AES, TEM, nitrogen adsorption, and particle size analysis. It allowed revealing certain processes: transformation of montmorillonite structure which appears in the leaching of interlayer and octahedral cations and protonation of the interlayer and -OH groups at octahedral sheets. In turn, changes in the structure of the 2:1 layer of montmorillonite and its interlayer result in significant alterations in the properties: reduction of cation exchange capacity and an increase of specific surface area. Acid treatment also leads to a redistribution of particle sizes and changes the pore system. The results of the work showed that bentonite clays retain a significant portion of their adsorption properties even after a prolonged and intense thermochemical treatment $\left(1 \mathrm{M} \mathrm{HNO}_{3}, 60^{\circ} \mathrm{C}, 108 \mathrm{~h}\right)$.
\end{abstract}

Keywords: engineered barriers; bentonite clays; thermochemical treatments; montmorillonite; structural modification; adsorption properties

\section{Introduction}

Clay minerals are widely used in various industries including radioactive waste management as a component of barrier systems for waste disposal. These systems are used for radioactive waste repositories of different levels of activity and are intended to provide safe storage for several 
hundreds or thousands years due to their high adsorption capacity for radionuclides and low water permeability [1-3].

Bentonite buffer between containers and the tunnel walls achieves several strategic outcomes at once: it provides access restriction of groundwater to the radioactive waste (RW) creating the conditions under which mass transfer between the waste and underground waters is only possible by diffusion; it suppresses migration of the radionuclides in colloidal form into the groundwater; it ensures effective sorption of radionuclides after possible depressurization of radioactive waste containers; it seals open cracks and large pores in the rocks due to the high swelling capacity, etc. [2].

One of the main components of the engineered barriers is bentonite, which contains $70-95 \%$ montmorillonite, dioctahedral specie of the smectite mineral group. Montmorillonite is a 2:1 type hydrous aluminosilicate with the octahedral sheet "sandwiched" between two tetrahedral sheets. Cation substitution in tetrahedral and mostly in octahedral sites provides a negative layer charge of about $0.2-0.5 \mathrm{eV}$. Layer charge is compensated by the introduction of exchangeable interlayer cations $\left(\mathrm{Na}^{+}, \mathrm{Ca}^{2+}, \mathrm{Mg}^{2+}\right.$, etc.) usually in hydrated form [4-8] which in turn provides adsorption sites on the inner and outer surface of the crystal. These particularities of montmorillonite structure determine specific properties of bentonite clays, especially high adsorption capacity towards heavy metals such as cesium, plutonium etc., which are commonly found in radioactive wastes.

Construction concept of waste disposal in the Russian Federation also includes the use of bentonite clay as a component of an engineered multi-barrier system $[9,10]$. According to current concepts, a bentonite barrier must retain its properties for over thousands of years. Thus, when analyzing the prospects of using bentonite clays, one needs to consider not only their sorption properties in their natural state, but a possible loss of sorption capacity and other parameters needed to preserve the stability of a bentonite barrier in aggressive environments. The most aggressive environment for bentonite clays is acid solutions. A number of processes take place under acid treatment and lead to a significant transformation of the structure and properties of montmorillonite bentonite clays [11-14]. A significant increase in the specific surface of the acid-modified clays promotes wide use of such material for removal of heavy metals, radionuclides and for oil refining [15-19]. The transformation of the structure and properties of bentonite under the influence of acids, mostly under sulfuric and hydrochloric acids, have been studied by different authors [20-26]. Using ultrasound and microwaves in addition to an acid treatment intensifies smectite mineral transformation [27]. In industry, acid-modified bentonites are most commonly used as catalysts [28-32].

In Russia, studies have been conducted to identify the most thermochemically resistant bentonite in order to determine the most appropriate bentonite clay for engineered barriers for waste disposal. The increase of the temperature in the vicinity of radioactive waste occurs due to radioactive decay. Thermochemical effects were modeled based on inorganic acid solutions (nitric and hydrochloric) at elevated temperatures. Due to its toxicity, nitric acid is not used in the chemical industry for the production of modified materials. Currently in Russia, there are plants that still dump liquid radioactive waste into deep layers of geological structures and in artificial surface repositories [33-37]. Nitric acid is used to prepare liquid radioactive waste for disposal. These concepts are obsolete and are being withdrawn from use. Bentonite is also used to bury surface basins, such as Lake Karachai [38].

However, in the long run, bentonite clays may be affected by aggressive fluids that are most likely to decrease insulating properties of the barrier. The aim of this study was to evaluate the mechanism of montmorillonite transformation under the acid solution treatment as well as its influence on bentonite properties.

\section{Materials and Methods}

Fine clay fractions $(<1 \mu \mathrm{m})$ separated from bentonites from Mukhortala (Buriatia, sample Mt-M) and Taganskoye (Kazakhstan, sample Mt-T1 and Mt-T2 (numbers "1" and "2" correspond to different treatments as will be shown below)) deposits were used for this study. Montmorillonite content in Mt-T and Mt-M sample were 70\% and 97\%, respectively. Impurities in Mt-M sample were presented by 
$20-30 \%$ opal C/A, which could not be removed with the sedimentation technique, and quartz (about 2-3\%) in Mt-T sample.

All experiments on acid treatment were carried out in closed systems under static conditions. For this purpose, bentonite samples were placed in sealed vessels with acid solution in a weight ratio of 1:100. Vessels were in turn placed in an oven and aged for the desired time. The experiments with $\mathrm{HCl}$ solutions $(0.125,0.25,0.5,1,3 \mathrm{M})$ were carried out at room temperature for 7 days (Mt-T1 and Mt-M samples) and with $1 \mathrm{M} \mathrm{HNO}_{3}$ solutions (Mt-T2 sample) at $60^{\circ} \mathrm{C}$ for $12,36,50$, and $108 \mathrm{~h}$. The bentonite samples from the Taganskoye deposit have quite a different composition and were named Mt-T1 for the experiment with $\mathrm{HCl}$ solution and Mt-T2 for the experiment with $\mathrm{HNO}_{3}$ solution. Hydrochloric acid treatment was conducted under the conditions accepted in chemical industry for modified bentonite production. Experiments with nitric acid treatment were conducted at high temperatures in order to simulate the conditions that may occur during liquid radioactive waste disposal.

Initial and modified samples were analyzed with a series of methods. X-ray diffraction patterns were obtained with X-ray diffractometer Ultima-IV (Rigaku, Tokyo, Japan) acquired with the funding of Moscow State University Development Program $(\mathrm{Cu}-\mathrm{K} \alpha$ radiation, semiconductor 1D detector $\mathrm{D} /$ Tex-Ultra, scan range $3-65^{\circ}(2 \theta)$, scan speed $5^{\circ} / \mathrm{min}$ and step- $0.02^{\circ}(2 \theta)$ ). Partially oriented specimens were prepared by pressing powder into a sample holder.

The chemical analyses of the solids were carried out by means of inductively coupled plasma atomic emission spectrometry (ICP-AES) using ICPE-9000 equipment (Shimadzu, Kyoto, Japan).

Excessive pressure and surface leveling leads to partial orientation of the montmorillonite particles in the specimen plane. We did not succeed in preparing samples with a good degree of particle orientation from drops of aqueous suspensions because some samples had been significantly modified after the treatment so they could not form thin films on a glass surface. The results were analyzed according to Drits, Kossovskaya [4], Moore and Reynolds [5]. Mineral composition was estimated using the Rietveld method [39] with PROFEX GUI for BGMN [40].

Fourier transform infrared spectroscopy analysis was carried out using FTIR spectrometer Vertex 80v equipped by DTGS detector and KBr beam-splitter (Bruker, Ettlingen, Germany). The adsorption spectra recordings were performed in vacuum in the $4000-400 \mathrm{~cm}^{-1}$ wavelength range with 256 scans for each sample and the resolution of $4 \mathrm{~cm}^{-1}$. Samples were prepared as pressed KBr-pellets: $0.5 \mathrm{mg}$ of sample was dispersed in $200 \mathrm{mg}$ of $\mathrm{KBr}$; this mixture was placed in a $13 \mathrm{~mm}$ pellet die and pressed in vacuum for $1 \mathrm{~h}$. Spectra manipulations were performed using the OPUS 7.1 software (Bruker, Ettlingen, Germany). Baseline correction was made automatically by Concave Rubberband method with 64 baseline points and 10 iterations.

Natural montmorillonites (Mt-M, Mt-T1, Mt-T2) as well as some samples after treatment were selected based on the results of X-ray diffraction studies (Mt-M-3.0 M HCl; Mt-T1-0.25 M and $0.5 \mathrm{M} \mathrm{HCl} ; 12$ and $108 \mathrm{~h}$ ) for further investigation by high-resolution transmission electron microscopy (HRTEM) using JEM-2100 with an X-Max attachment for X-ray energy dispersive analysis.

Evaluation of a specific surface area was carried out using the Analyzer Quadrasorb SI/Kr (Quantachrome Instruments, Boynton Beach, FL, USA). Adsorption was performed at the liquid nitrogen temperature $(77.35 \mathrm{~K})$. Nitrogen with a $99.999 \%$ purity served as an adsorbate. Helium grade $6.0(99.9999 \%)$ was used for the volume calibration of the measuring cells. Calculation was carried out by the BET multiple-point isotherm in the range of P/P0 from 0.05 to 0.30 . Samples were pre-dried in vacuum at $100^{\circ} \mathrm{C}$.

Cation exchange capacity was determined by triethylenetetramine copper complex $[\mathrm{Cu}(\mathrm{Trien})]^{2+}$ adsorption method [41].

Particle size distribution was evaluated with the laser diffraction technique by Fritsch ANALYSETTE 22 NanoTec (Fritsch, Idar-Oberstein, Germany) equipped with $70 \mathrm{~W}$ and $36 \mathrm{kHz}$ ultrasonic emitter in the size range $0.01-1000 \mu \mathrm{m}$ Data processing was carried out by algorithm based on Fredholm integral equations. 


\section{Results and Discussion}

\subsection{Transformation of the Montmorillonite Structure under Acid Treatment}

Considerable crystal-chemical transformations-in particular, changes of montmorillonite micromorphology and adsorption characteristics-were detected under treatment with hydrochloric and nitric acid solutions. A variety of processes that modified structure and properties of montmorillonite particles were observed during the treatment with inorganic acid solutions: dissolution of carbonates and feldspars, destruction of the most defective phyllosilicate phases (e.g., nanosized smectites), removal of cations from the interlayer spacing, substitution of interlayer cations with oxonium ion, leaching of the octahedral cations, and finally, the complete destruction of the structure.

Studied montmorillonite samples are characterized by the heterogeneous composition of the interlayer: $\mathrm{Ca}^{2+}$ and $\mathrm{Mg}^{2+}$ for the Mt-M sample $\left(\mathrm{d}_{001}=15.3 \AA\right)$, and $\mathrm{Ca}^{2+}, \mathrm{Mg}^{2+}$ and $\mathrm{Na}^{+}\left(\mathrm{d}_{001}=13.7 \AA\right.$ and $\mathrm{d}_{001}=13.9 \AA$, respectively) for Mt-T1 and Mt-T2 samples (Figure 1, Table 1). Presence of $\mathrm{Na}^{+}$in the montmorillonites from the Taganskoye deposit was also confirmed in previous studies [26,42,43].

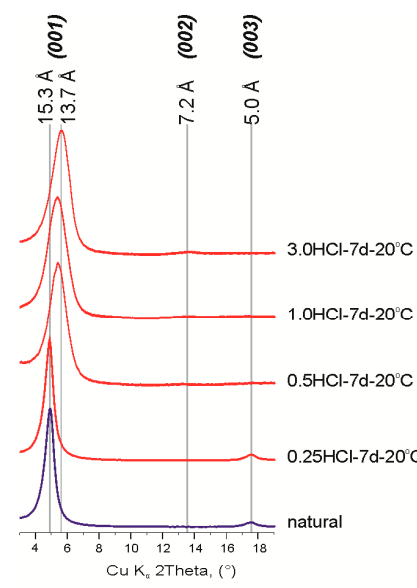

(a)

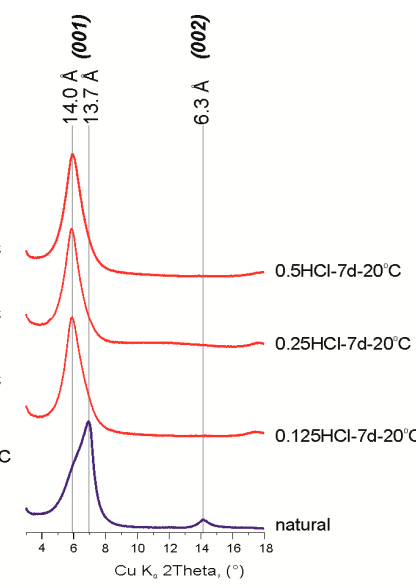

(b)

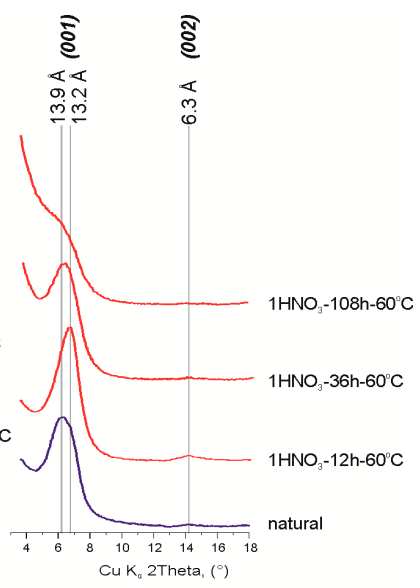

(c)

Figure 1. Fragments of the $\mathrm{X}$-ray diffraction patterns of natural and treated montmorillonites: (a) Mt-M; (b,c) Mt-T. Abbreviations: $3.0 \mathrm{HCl}, 1 \mathrm{HNO}_{3}$, type and concentration (given in mol/L) of acid; $7 \mathrm{~d}$ (days), $12 \mathrm{~h}$ (hours), time of treatment, $20,90^{\circ} \mathrm{C}$, temperature of treatment.

Table 1. Changes of the structural parameters, textural and adsorption characteristics of montmorillonites due to acid activation (Specific Surface Area: $\mathrm{S}_{\mathrm{BET}}$, Total Pore Value: $\mathrm{V}_{\Sigma}$, Cation Exchange Capacity: CEC).

\begin{tabular}{|c|c|c|c|c|c|c|c|c|c|}
\hline \multirow[b]{2}{*}{ Sample } & \multicolumn{3}{|c|}{ Treatment } & \multirow{2}{*}{$\begin{array}{c}\text { Interlayer } \\
\text { Space } \mathrm{d}_{001}(\AA)\end{array}$} & \multirow{2}{*}{$\begin{array}{l}\text { Particle Thickness } \\
\text { h(001) (CSR) (nm) }\end{array}$} & \multirow{2}{*}{$\begin{array}{l}\text { Number of } \\
\text { Layers (N) }\end{array}$} & \multirow{2}{*}{$\begin{array}{c}\mathrm{S}_{\mathrm{BET}} \\
\left(\mathrm{m}^{2} / \mathrm{g}\right)\end{array}$} & \multirow{2}{*}{$\begin{array}{c}\mathrm{V}_{\Sigma} \\
\left(\mathrm{cm}^{3} / \mathrm{g}\right)\end{array}$} & \multirow{2}{*}{$\begin{array}{c}\text { CEC } \\
\text { (meq/100 g }\end{array}$} \\
\hline & $\begin{array}{c}\text { Acid } \\
(\mathrm{mol} / \mathrm{L})\end{array}$ & $\begin{array}{c}\mathrm{T} \\
\left({ }^{\circ} \mathrm{C}\right)\end{array}$ & $\begin{array}{c}\text { Time } \\
\text { Days/Hours }\end{array}$ & & & & & & \\
\hline & \multicolumn{9}{|c|}{$\mathrm{HCl}$} \\
\hline \multirow{5}{*}{ Mt-M } & - & - & - & 15.3 & 10.7 & 7 & 77 & 0.211 & 46 \\
\hline & 0.25 & 20 & $7 \mathrm{~d}$ & 15.3 & 12.2 & 8 & 79 & 0.219 & 43 \\
\hline & 0.5 & 20 & $7 \mathrm{~d}$ & 14.0 & 7.0 & 5 & 92 & 0.243 & - \\
\hline & 1.0 & 20 & $7 \mathrm{~d}$ & 14.0 & 5.6 & 4 & 95 & 0.256 & 49 \\
\hline & 3.0 & 20 & $7 \mathrm{~d}$ & 13.7 & 5.5 & 4 & 101 & 0.328 & 64 \\
\hline \multirow{5}{*}{ Mt-T1 } & - & - & - & 13.7 & 9.6 & 7 & 42 & 0.074 & 75 \\
\hline & 0.125 & 20 & $7 \mathrm{~d}$ & 14.0 & 7.0 & 5 & 45 & 0.084 & 65 \\
\hline & 0.25 & 20 & $7 \mathrm{~d}$ & 14.0 & 7.0 & 5 & 50 & 0.095 & 64 \\
\hline & 0.5 & 20 & $7 \mathrm{~d}$ & 14.0 & 5.6 & 4 & 51 & 0.083 & 70 \\
\hline & \multicolumn{9}{|c|}{$\mathrm{HNO}_{3}$} \\
\hline \multirow{4}{*}{ Mt-T2 } & - & - & - & 13.9 & 8.2 & 6 & 67 & 0.085 & 86 \\
\hline & 1 & 60 & $12 \mathrm{~h}$ & 14.0 & 7.0 & 5 & 110 & 0.114 & 58 \\
\hline & 1 & 60 & $36 \mathrm{~h}$ & 14.0 & 7.0 & 5 & 191 & 0.192 & 56 \\
\hline & 1 & 60 & $108 \mathrm{~h}$ & 13.8 & 5.5 & 4 & 301 & 0.353 & 40 \\
\hline
\end{tabular}


Treatment of Mt-M sample with hydrochloric acid solution with various concentrations leads to partial protonation of the interlayer which is observed by a decrease in $\mathrm{d}_{001}$ values and changes in basal reflections series from $\mathrm{d}_{001}=15.3 \AA, \mathrm{d}_{003}=5.0 \AA, \mathrm{d}_{005}=3.0 \AA$ to $\mathrm{d}_{001}=13.7 \AA$. $\mathrm{d}_{002}=7.2 \AA$, $\mathrm{d}_{003}=4.8 \AA, \mathrm{d}_{004}=3.6 \AA$ (Figure 1). These changes can be related with leaching of the interlayer cations $\left(\mathrm{Ca}^{2+}\right.$ and $\left.\mathrm{Mg}^{2+}\right)$ and partial protonation of interlayer space i.e., substitution of interlayer cations with oxonium ion $[44,45]$ because protonation of $\mathrm{Ca}-\mathrm{Mg}$ montmorillonite proceeds much faster than that of Na-forms [43].

Early, we demonstrated that the chemical composition and structural characteristics of $\mathrm{Mt}$ depended on the $\mathrm{HNO}_{3}$ and $\mathrm{HCl}$ concentration [26,32]. Changes of chemical composition and interlayer space were negligible after modification of montmorillonite under the concentrations up to $0.5 \mathrm{M}$. These changes were noticeable only after treatment with $3.0 \mathrm{M}$ acid. Here we investigated effect of exposure time of $1 \mathrm{M} \mathrm{HNO}_{3}$ at $60^{\circ} \mathrm{C}$ on chemical composition of Mt-T2. The main results are shown in the Table 2. Experimental data point that leaching of interlayer cation is observed after the treatment with $1 \mathrm{M} \mathrm{HNO}_{3}$ for $12 \mathrm{~h}$.

Table 2. Chemical composition of MM-T2 natural and modified by $1 \mathrm{M} \mathrm{HNO}_{3}$ at $60^{\circ} \mathrm{C}$.

\begin{tabular}{cccccccc}
\hline \multirow{2}{*}{ Time (h) } & \multicolumn{7}{c}{ Chemical Composition (wt \%) } \\
\cline { 2 - 8 } & $\mathbf{S i}$ & $\mathbf{A l}$ & $\mathbf{F e}$ & $\mathbf{M g}$ & $\mathbf{C a}$ & $\mathbf{N a}$ & $\mathbf{S i} / \mathbf{A l}$ \\
\hline- & 26.4 & 7.8 & 3.9 & 1.9 & 0.6 & 2.4 & 3.4 \\
12 & 27.3 & 7.6 & 3.7 & 1.6 & trace & trace & 3.6 \\
36 & 28.0 & 6.9 & 3.2 & 1.4 & 0.2 & trace & 4.1 \\
108 & 31.8 & 5.0 & 2.0 & 0.9 & trace & trace & 6.3 \\
\hline
\end{tabular}

Profile alignment of basal reflections (001) and displacement of maximum $13.7 \AA$ to $14.0 \AA$ was observed after treatment of Mt-T1 sample with hydrochloric acid solution. Irregular profile shape of $\mathrm{d}_{001}$ reflection indicates the presence of two possible montmorillonite phases with different interlayer cations in the sample. This was also found by other researchers of the Taganskoye montmorillonite deposit [43]. Since any other impurities except quartz were not found in this sample, the described change in the XRD patterns can be attributed to the partial destruction (dissolution) of the most defective and probably nanosized particles of Na-montmorillonite.

Treatment of Mt-T sample with $1 \mathrm{M} \mathrm{HNO}_{3}$ solution for $12 \mathrm{~h}$ leads to a displacement of the $\mathrm{d}_{001}$ reflection from 13.9 to $13.2 \AA$ with an increase of its intensity. This fact is explained by the dissolution of the defective part of the montmorillonite and enhancement of the interlayer ordering by partial substitution of $\mathrm{Ca}^{2+}$ and $\mathrm{Mg}^{2+}$ cations. Further treatment of the sample with nitric acid solution reduces the layer stacking ordering degree and leads to disintegration of montmorillonite 2:1 layer structure. In XRD patterns, the described process is manifested by a decrease in the peaks intensity and broadening of the basal reflections until the complete disappearance except (001) reflection. Displacement of the (001) reflection back to $13.9 \AA$ after the 36 and $108 \mathrm{~h}$ of treatment can be explained by the $\mathrm{Mg}$ and $\mathrm{Al}$ octahedral cations leaching and their migration into the interlayer space of montmorillonite.

The changes in the sizes of the coherent scattering domains (CSD) along the c-axis were calculated in accordance with the Scherrer equation for the (001) reflection of natural and modified montmorillonites (Table 1). In general, the size of CSD along the c-axis corresponds with the crystallite thickness [46]. The average crystallite thicknesses of the samples equals $10.7 \mathrm{~nm}$ which corresponds to 7 layers $(7 \mathrm{~N}), 9.6 \mathrm{~nm}(7 \mathrm{~N}), 8.2 \mathrm{~nm}(6 \mathrm{~N})$ for natural Mt-M, MtM-T1 and Mt-T2 samples respectively, and to $5.5-5.6 \mathrm{~nm}(4 \mathrm{~N})$ for the acid treated montmorillonites. A decrease of CSD sizes is related to a consequent disintegration of montmorillonite particles and increase of the stacking faults quantity.

The increase of the adsorbed water bands on IR spectra in the range of $4000-2500 \mathrm{~cm}^{-1}$ probably indicates a decrease of crystallite size (Figure 2a) after the treatment of Mt-T2 sample with $\mathrm{HNO}_{3}$ acid for $108 \mathrm{~h}$. Previous studies of Mt-M and Mt-T1 samples treated with $\mathrm{HCl}$ acid [26] showed the reduction of band intensity at $841-845 \mathrm{~cm}^{-1}(\mathrm{Al}-\mathrm{Mg}-\mathrm{OH}), 882 \mathrm{~cm}^{-1}(\mathrm{Al}-\mathrm{Fe}-\mathrm{OH})$ and $914-926 \mathrm{~cm}^{-1}$ (Al-Al-OH), 
which indicates the leaching of $\mathrm{Al}^{3+}, \mathrm{Mg}^{2+}$ and $\mathrm{Fe}^{3+}$ cations from the octahedral sites [44-49]. Reduction of the band intensities at 925 and $876 \mathrm{~cm}^{-1}$ is shown at Figure 2c. It corresponds to Al-Al-OH and $\mathrm{Al}-\mathrm{Fe}-\mathrm{OH}$ vibrations in the structure of octahedral sheet of montmorillonite (Mt-T2 sample) during the treatment with the nitric acid. It may indicate a leaching of $\mathrm{Fe}^{3+}$ and $\mathrm{Al}^{3+}$ from the octahedral sites.

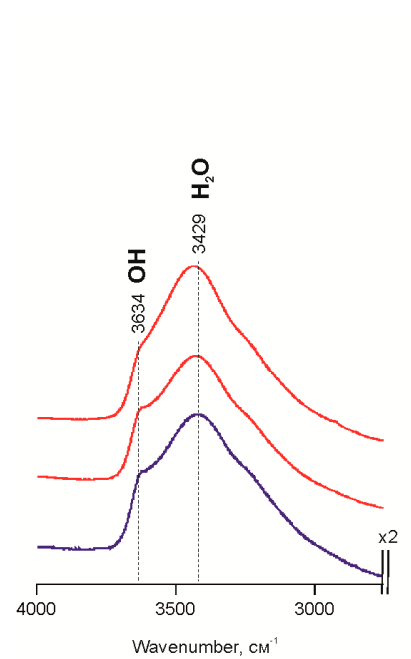

(a)

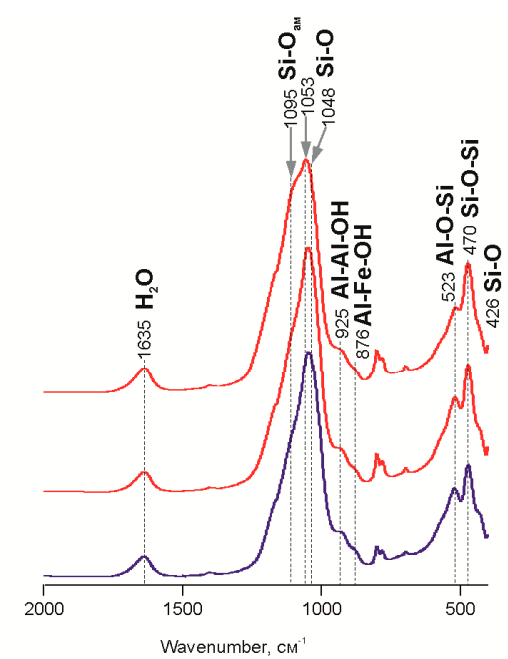

(b)

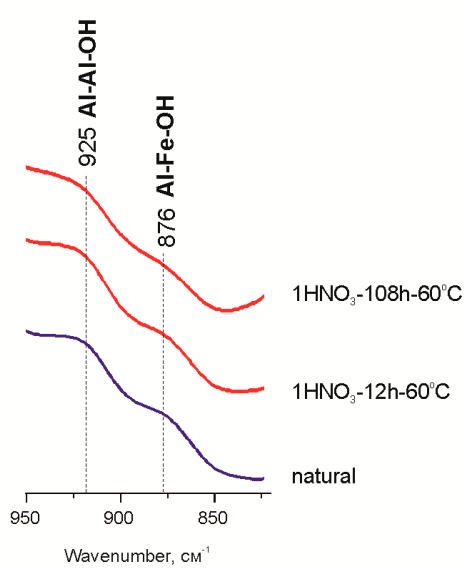

(c)

Figure 2. Areas of interest on MM-T IR spectra before and after treatment with $1 \mathrm{M} \mathrm{HNO}_{3} 60{ }^{\circ} \mathrm{C}$ : $(\mathbf{a}, \mathbf{b})$ the characteristic part of spectrum; (c) a magnified part of the spectra.

Leaching of the octahedral cations leads to modifications of the interaction between the octahedral and tetrahedral sheets in the 2:1 layer and, as a result, to the partial destruction of octahedral sheets. Alterations in FTIR data revealed as decreasing intensities of the bands related to octahedral $\mathrm{Al}, \mathrm{Fe}$ and $\mathrm{Mg}$ and exchangeable $\mathrm{Ca}, \mathrm{Na}$ and $\mathrm{Mg}$ correlate with changes in chemical composition shown above. Therefore, the structural units comprised of the tetrahedral sheet fragments are released from the 2:1 structure, which corresponds to "Si-O $\mathrm{O}_{\text {free" }}$ " vibrations- $1095 \mathrm{~cm}^{-1}[11,15,21,50]$. Changes in the $\mathrm{Si}-\mathrm{O}-\mathrm{Si}$ band profile within the range of $1100-1050 \mathrm{~cm}^{-1}$ (Figure $2 \mathrm{~b}$ ) indicate transformation of interaction within the tetrahedral sheet. In particular, displacement of the maximum in the natural sample from 1050 to $1095 \mathrm{~cm}^{-1}$ after treating it with $1 \mathrm{M} \mathrm{HNO}_{3}$ for $108 \mathrm{~h}$ indicates the increase of amorphous silica content due to partial destruction of the tetrahedral sheet which is confirmed by chemical analysis data as an increase in Si content in powder samples.

Transmission electron microscopy (TEM) allows collection of data at the level of crystal lattice and helps to estimate structural transformation of montmorillonite, properties of surface and interactions between the layers during its treatment with inorganic acid solutions, and changes in montmorillonite particles' chemical composition [51]. In natural samples from the Tagansoye deposit (Figure 3a) among the laminar montmorillonite particles with a size of 1-2 $\mu \mathrm{m}$, there is a significant amount of small and thin nano-sized particles that cover the specimen and produce grey background in micrographs. Particle identification was carried out based on microdiffraction patterns and micro-area chemical analysis. The nanosized phase is characterized by a higher content of $\mathrm{Na}$ as an interlayer cation and Fe is located in the octahedral sheet due to the isomorphic substitution of Al. Under hydrochloric acid with lower concentrations, as well as under the treatment with nitric acid for shorter periods, almost full dissolution of nano-sized particles as the less acid resistant phase takes place and the grey background on micrographs is not observed. Besides, these laminar particles have a lot of folded edges which are not usually observed in acid-modified montmorillonites. Bentonites from Mukhortala deposit (Mt-M) contain a lot of opal distributed in pores between thin and relatively thick laminar montmorillonite particles and also on their relatively clean surfaces (Figure 3c). 


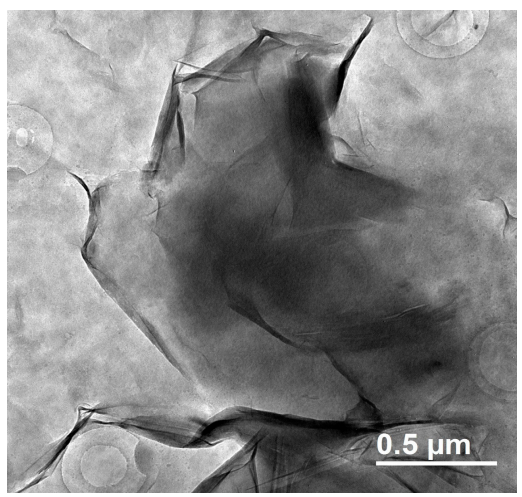

(a)

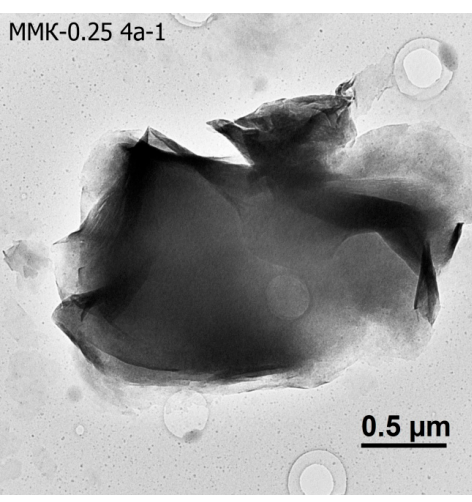

(b)

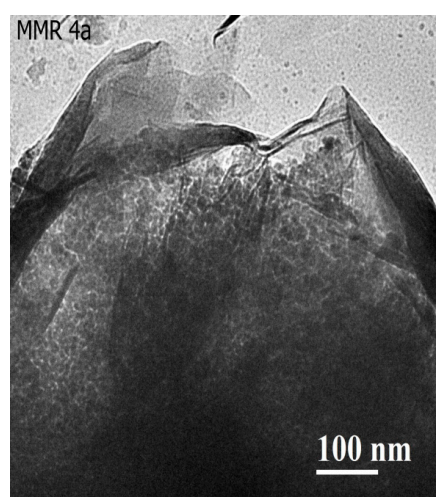

(c)

Figure 3. Transmission electron microscopic (TEM) images: (a) natural particles from the sample MM-T; (b) treated with $0.25 \mathrm{M} \mathrm{HCl}$; (c) natural sample MM-M.

Studied samples of the natural montmorillonites are characterized by peculiar particle morphology that is typical for montmorillonites of different genesis and by a wide spread of welted edges, which can be useful for obtaining pictures of the lattices (Figure 4). Images obtained from edges of natural montmorillonite (Mt-T2 sample) show the lattice stripes that correspond to the basal planes (Figure $4 a, b$ ). The width of the areas with lattice stripes is about $23-32 \mathrm{~nm}$. The value of the interlayer space for different particles varies within the range from 10.5 to $11.8-12.3 \AA$.

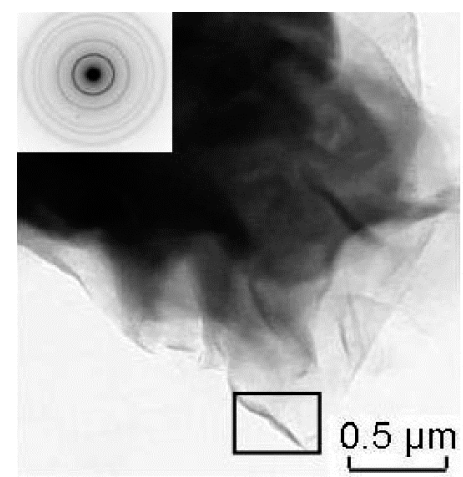

(a)

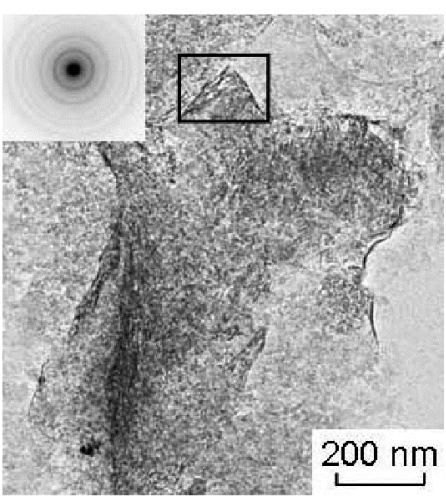

(c)

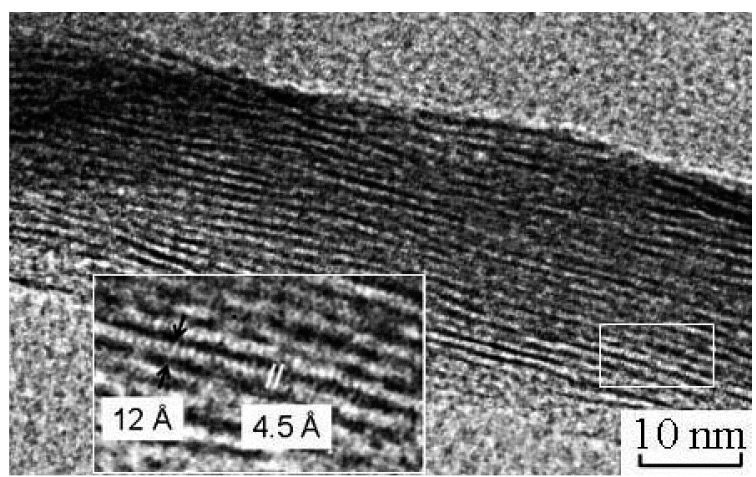

(b)

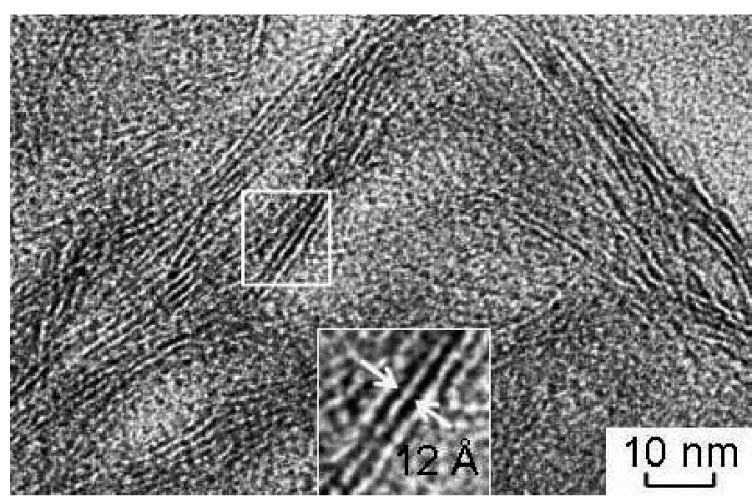

(d)

Figure 4. Transmission electron microscopic (TEM) images of natural montmorillonite particles (a,b), and treated with $1 \mathrm{M} \mathrm{HNO}_{3}$ for $108 \mathrm{~h}(\mathbf{c}, \mathbf{d})$. Microdiffraction figures are located at enlarged areas. $(\mathbf{b}, \mathbf{d})$ high resolution images from the folded edge of the montmorillonite particles (area locations are shown as black rectangles in Figure (a,c), respectively). 
The lattice stripes of different particles can be pulled simultaneously, maintaining a noticeable distance between the adjacent bands or showing some curving of the surface, which indicates only a small change of interlayer space along the layers. Moreover, there are areas of the image with two-dimensional lattice stripes (Figure $4 \mathrm{~b}$ ). Basal lattice stripes are crossed by lattice stripes with an interlayer space of $4.5 \AA$ which corresponds to planes (020) and indicates local manifestations of coherence in stacking of adjacent layers.

Microaggregate surface of Mt-T2 sample became uneven as the result of the treatment with $\mathrm{HNO}_{3}$ for $108 \mathrm{~h}$. This effect can be seen only at some fragments of the images with folded edges with typical parallel basal lattice stripes from planes (001). It correlates to the small packs of 2-3 layers (Figure $4 \mathrm{~b}$ ) less than $25 \mathrm{~nm}$ long. The interlayer spacing 12-14 $\AA$ indicates the presence of initial montmorillonite. The observed pattern of distribution of the basal lattice stripes reflects the nano-level changes in the surface morphology of montmorillonite. It implies an existence of thin packages of layers where the planes (001) are arranged perpendicularly to the surface of the particles. This effect in particular leads to an increase of its surface and the occurrence of active sites for the selective sorption of heavy metals and radionuclides.

\subsection{Transformation of Montmorillonite Adsorption Properties under Acid Treatment}

Specific surface area (BET) and cation exchange capacity (CEC) can be qualified as characteristics of adsorption properties of bentonite clays. CEC values of montmorillonites depend most significantly on the amount of isomorphic substitutions in octahedral sites. In turn, specific surface area is primarily controlled by degree of fineness, amount of impurities, particle charge, their ability to coagulate, etc. Mt-M sample contains a significant amount of opal which provides a relatively higher specific surface area than that of Taganskoye deposit samples (Mt-T1 and Mt-T2). Commonly, specific surface area (BET) values are in direct relationship with CEC value [52]. Increasing of BET value leads to an increase of CEC value and vice versa. In most cases, the above is true for natural soils with different mineral compositions [46]. However, the ratio of these indexes for montmorillonites of different composition may be in a more complex relationship. This dependence can be clearly seen in the Table 1 as an increase of specific surface area and a decrease in cation exchange capacity due to the acid treatment.

Coherent scattering domain sizes are commonly used to analyze the size of crystallites [46,53-55]. There is a cumulative index of physical-chemical activity of the most clay minerals which have correlations with specific surface area and adsorption characteristics. Thus, reduction of crystallite size should lead to an increase of specific surface area, which is shown in the study (Table 1).

At the same time, an increase of the specific surface area appears mostly in the samples which have the greatest structural changes. Thus, in the montmorillonite sample from Taganskoye deposit, treated with $\mathrm{HNO}_{3}$ for a long period of time, the increase of the specific surface area was $301 \mathrm{~m}^{2} / \mathrm{g}$ compared to $67 \mathrm{~m}^{2} / \mathrm{g}$ in the natural sample. Also, considerable changes were observed in the sample with montmorillonite from the Mukhortala deposit (from 77 to $101 \mathrm{~m}^{2} / \mathrm{g}$, respectively).

The average pore size in all samples is approximately $5 \mathrm{~nm}$ and it remains constant during the experiments, while the total pore volume has been changed slightly for Mt-M and Mt-T1 samples and considerably so for Mt-T2 sample. This fact cannot be related only to the size decrease. In this way, the observed increase of specific surface area, as well as the total pore volume is related to the formation of porous structure due to the modification of montmorillonites under the acid treatment.

As a result of the treatment, a regular change is observed in the chemical composition of montmorillonite (Table 2). First of all, the reduction of $\mathrm{Ca}, \mathrm{Mg}$, $\mathrm{Fe}$, and $\mathrm{Al}$ content and the increase of $\mathrm{Si}$ content is found in all samples after dissolving the nano-sized phases of montmorillonite from Taganskoye deposit. The most significant changes were found in the Mt-T2 sample treated with $\mathrm{HNO}_{3}$ acid solution for $108 \mathrm{~h}$. The increase of Si content in montmorillonite samples subjected to the intensive acid treatments connected with subsidence of amorphous silica formed during the destruction of tetrahedral sheets of 2:1 layers on the particle surface and its accumulation in the micropores. 
Protonation of $\mathrm{Al}$ bond pairs in the octahedron transforms it from 4-coordination to 6-coordination [23] and leads to the modification of octahedral and tetrahedral sheets and to an appearance of micropores simultaneously decreasing the number of octahedral cations. Changes in the layer stacking and particles' micromorphology results in mesopore formation $[14,45]$. Structural transformations are shown simplified in Figure 5. Thus, there is an increase of specific surface area and pore space both capable of large cation sorption, e.g., Cs.

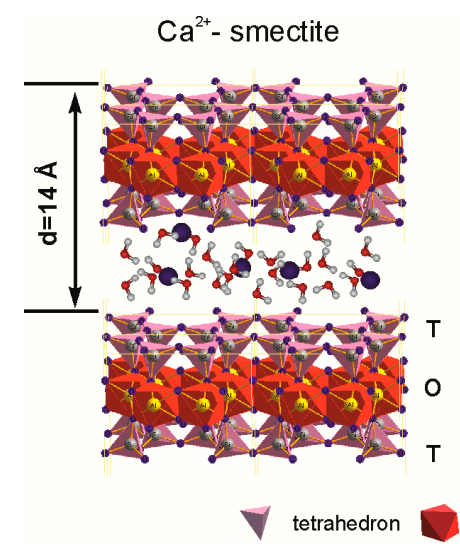

(a)

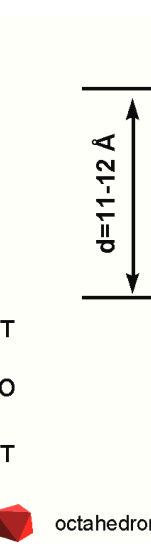

(ahedron
$\mathrm{H}^{+}$- smectite

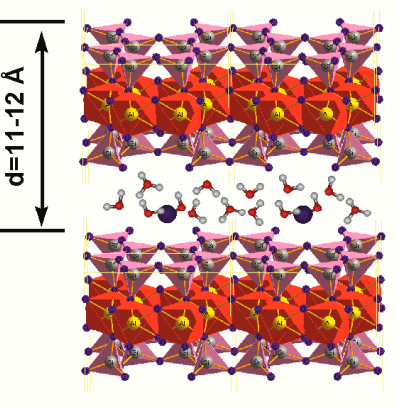

(b)

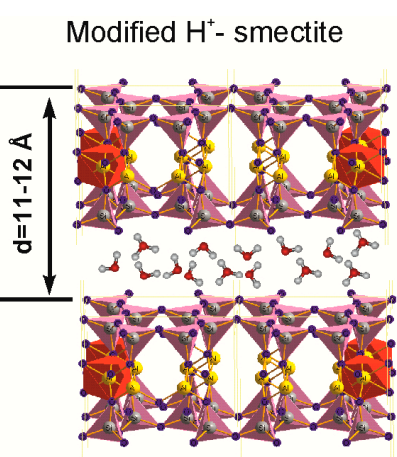

Lo water $\left(\mathrm{H}_{2} \mathrm{O}\right)$ >o $\left(\mathrm{H}_{3} \mathrm{O}\right)$

(c)

Figure 5. Schematic picture representing the structural changes in natural montmorillonite under the treatment with inorganic acid solutions: (a) natural Ca-montmorillonite; (b) partial protonation of interlayer space; (c) full protonation of interlayer space (H-smectite) and protonation of the OH-groups of the octahedral sheet and Al coordination change.

Critical values for describing the concepts of "micropores", "mesopores", and "macropores" vary in classifications developed for different science approaches. In engineering geology, for example, mesopore sizes are in the range of 10 to $1000 \mu \mathrm{m}$ and micropores are from 0.1 to $10 \mu \mathrm{m}$ [56]. V. Osipov and V. Sokolov in their morphometric investigations of soil microstructures with different composition [52] detailed the previously proposed classification of pore sizes. They divided micropores into thin $(0.1-10 \mu \mathrm{m})$, small $(1-10 \mu \mathrm{m})$, and large $(10-100 \mu \mathrm{m})$ ones, suggesting the lower limit for macropores as $100 \mu \mathrm{m}$.

There are other classifications to consider. For example, the International Union for Pure and Applied Chemistry (the IUPAC) recommended to distinguish pores size into macropores $(50 \mathrm{~nm})$, mesopores ( 2 to $50 \mathrm{~nm}$ ), and micropores (up to $2 \mathrm{~nm}$ ) [57-59]. The micropores are conventionally divided into thin ultramicropores (less than $0.7 \mathrm{~nm}$ ) and supermicropores that have an intermediate size between ultramicropore and mesopores.

In fact, all the pores in montmorillonite referred above of the size not larger than 6-9 $\mathrm{nm}$ for mesopores and 1-3 $\mathrm{nm}$ for micropores are predominantly involved in the adsorption [60]. The average pore size measured in natural and modified montmorillonites is about $5 \mathrm{~nm}$ which corresponds to interparticle pores according to Osipov and Sokolov [52]. At the same time, acid treatment, as shown above, leads to the appearance of pores in the structure of the layer (micropores) by partial leaching of octahedral cations, protonation of $\mathrm{OH}$-groups, and changes of $\mathrm{Al}^{3+}$ coordination. The above process does not lead to an increase of an average pore size, however, it results in an increase of the total pore volume (Table 1).

Mesopores of a size about $5 \mathrm{~nm}$ and a small amount of micro-pores with a diameter of about $3 \mathrm{~nm}$ are predominant in the natural montmorillonite. After treatment with hydrochloric acid with concentration up to a $3.0 \mathrm{M}$ at room temperature for 7 days, significant changes in the structure of the pore space were not observed, which also can be seen below in the $\mathrm{N}_{2}$ adsorption-desorption isotherms. Treatment with $1 \mathrm{M} \mathrm{HNO}_{3}$ for $12 \mathrm{~h}$ does not lead to significant changes of the pore space 
either. The most significant changes were observed as a result of treatment for $108 \mathrm{~h}$ (Figure 6a): the amount of 5-5.5 nm mesopores significantly increases and micropores with an average diameter of $3.5 \mathrm{~nm}$ appear which is not observed in natural montmorillonite samples. The particle size distribution changes even at low exposure times in the experiment with $1 \mathrm{M} \mathrm{HNO}_{3}$ (Figure $6 \mathrm{~b}$ ) from monomodal shape with a maximum at $50 \mu \mathrm{m}$ to a multimodal shape with peaks at $\sim 80,100,145$, and $200 \mu \mathrm{m}$. Thus, with increased micro- and mesoporosity, particle aggregation occurs that leads to the formation of relatively large aggregates of different sizes.

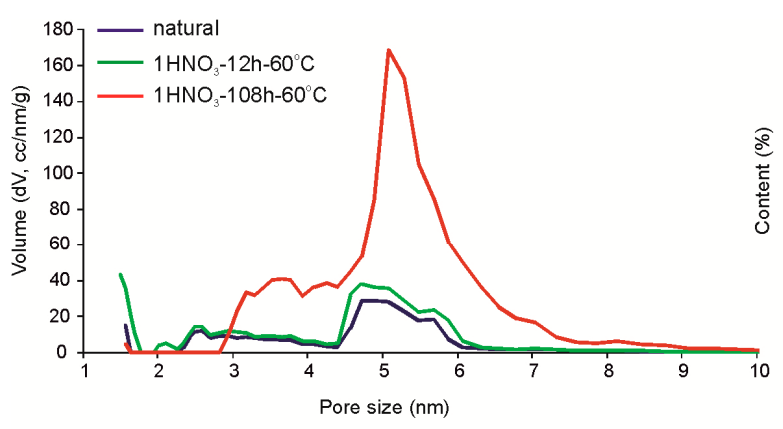

(a)

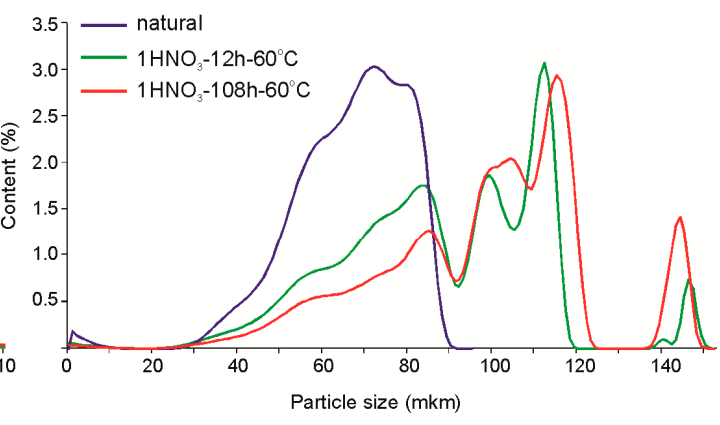

(b)

Figure 6. Changes of the porosity (a) and the particle size distribution (b) of Mt-T2 a sample due to exposure to $1 \mathrm{M} \mathrm{HNO}_{3}$ at $60^{\circ} \mathrm{C}$.

Adsorption-desorption isotherms of $\mathrm{N}_{2}$ are shown in Figure 6. As shown earlier, exposure to 0.25 and $0.5 \mathrm{M} \mathrm{HCl}$ for 7 days at room temperature results only in minor changes in the chemical composition (Table 2). The same tendency is observed in changes of $\mathrm{N}_{2}$ adsorption-desorption isotherms for samples Mt-M and Mt-T1 (Figure 6). Mt-T1 sample was treated only at $0.5 \mathrm{M} \mathrm{HCl}$ concentrations and is not shown in Figure 7 since the changes in the adsorption-desorption rates are within the error margin of the method.

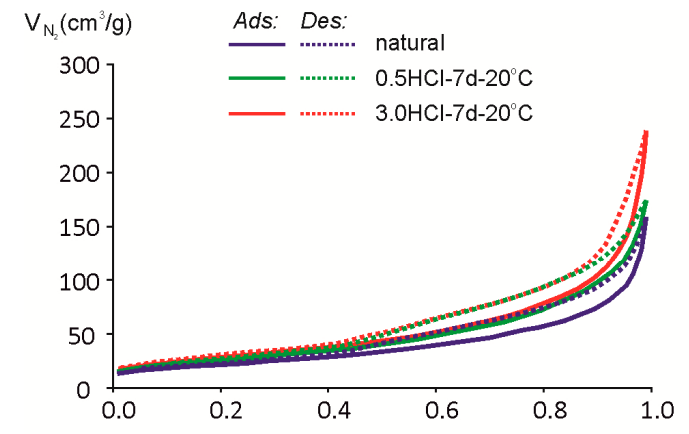

(a)

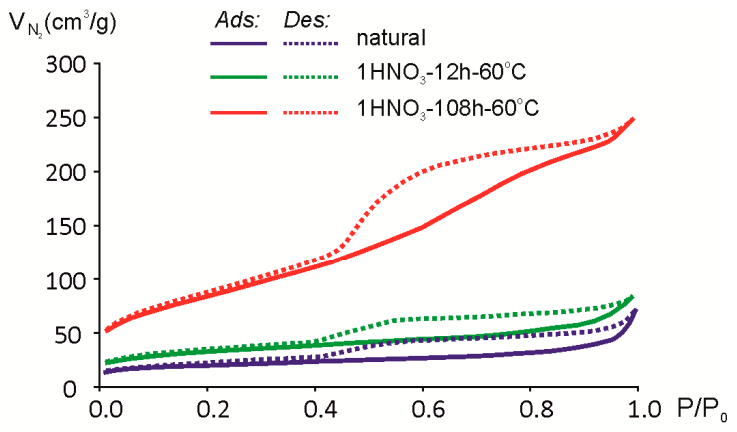

(b)

Figure 7. Isotherms of $\mathrm{N}_{2}$ adsorption (Ads)/desorption (Des) of montmorillonites: (a) Mt-M; (b) Mt-T2.

Hysteresis loop and the shape of the isotherm is close to the type IVa [61,62], which means that the natural and acid-modified montmorillonites studied can be characterized as mesoporous adsorbents where monolayer-multilayer adsorption is followed by capillary condensation. There is a significant amount of the micropores and mesopores so $\mathrm{N}_{2}$ adsorption/desorption isotherms cannot be described by one classical type only [61].

Hysteresis loops may have a different shape and, in the study of natural montmorillonite, can be attributed to the H3-H4 type [61]. Loops of this type correspond to the interaction between nonrigid lamellar particles. Smooth slope loops correspond to filling the micro- and mesopores. 
Increase in steepness after the acid treatment may be explained by an increase of the pore volume and the appearance of macro-porosity. The specific hysteresis loop of the sample Mt-T2 isotherm after prolonged exposure to $1 \mathrm{M} \mathrm{HNO}_{3}$ (Figure $7 \mathrm{~b}$ ) can be attributed to the type $\mathrm{H2}$ (b) [61]. This type of a desorption branch of the isotherm can be the result of a complex system of channel and pore formations and a partial blocking of them.

As a result of exposure to acid solutions, the hysteresis loop increases. In particular, it is noticeable after a prolonged influence of nitric acid at a high temperature (Figure 6b) when the hysteresis loop changes in a certain way.

The measured cation exchange capacity value (CEC) decreases from $86 \mathrm{meq} / 100 \mathrm{~g}$ in natural bentonite clay to $40 \mathrm{meq} / 100 \mathrm{~g}$ in bentonite samples with the longest time of the $\mathrm{HNO}_{3}$ solutions treatment for $108 \mathrm{~h}$ (Table 1). Such a decrease of CEC under the treatment with inorganic acid solutions (e.g., $\mathrm{HCl}$ and $\mathrm{H}_{2} \mathrm{SO}_{4}$ ) was described by other researchers [12]. Cation exchange capacity of bentonite clays is connected not only to montmorillonite content but primarily, to such structural particularities as layer charge and its distribution among octahedral sheets. As a result, treatment with inorganic acid solutions leads to layer charge reduction due to leaching of the octahedral cations and the structural degradation; all of which leads to a decrease in the cation exchange capacity. In addition, amorphous silica appeared as a result of the destruction of tetrahedral sheets. The silica can settle on the surface of montmorillonite particles and reduce its exchange capacity.

A lot of attention in the work on acid treatment of natural bentonite clay was dedicated to the issues of activation-i.e., improving the properties of modified clays in comparison with natural clays $[63,64]$. An increase of specific surface area and pore volume is observed in the course of the conducted experiments (Table 1). Leaching of the cations from interlayer space and octahedral positions results in a modification of layer charge and particles in general, this in turn affects the interaction of the individual particles between each other. As a result, the destruction of large aggregates, the restructuring of smaller ones, the appearance of an uneven surface, and the appearance of micropores on the site of octahedral grid take place. All the processes described above result in an increase of the total pore size and surface area. However, opportunities for cation exchange and its capacity are reduced due to layer charge modification and protonation of interlayer space.

\section{Conclusions}

The study concludes that an interlayer modification occurs even at early stages of treatment with $\mathrm{HCl}$ and $\mathrm{HNO}_{3}$ solutions. This modification involves partial substitution of interlayer cations, especially $\mathrm{Ca}$ and $\mathrm{Mg}$, to oxonium and partial protonation of the interlayer space. As the least stable components, natural nano-sized smectites and the most defective phase are completely dissolved in natural montmorillonite samples after acidic treatment.

Further treatment of montmorillonite structure with inorganic acid solutions (with increasing concentration and exposure period) leads to further modification of its structure accompanied by intense leaching of cations from the octahedral positions and partial penetration of leached octahedral cations into interlayer space. These transformations lead to partial protonation of $\mathrm{OH}$-groups, partial destruction of the octahedral sheets, and modification of the interaction between tetrahedral and octahedral sheets which changes layer charge and the nature of interaction between adjacent layers and partial amorphization of tetrahedral sheets. A decrease in the layer charge leads to a decrease in CEC.

As a result of structural transformation, specific surface area increases. Also, volume and pore diameters increase as well as micropores of a $3.5 \mathrm{~nm}$ diameter occur which is not typical for natural montmorillonites. As a consequence, particle size distribution changes. Due to the rise in micro- and mesoporosity, adsorption capacity of the acid-treated bentonite clays still remains high.

Modification of structural and adsorption characteristics with the acid treatment can be used to simulate behavior of the engineered barrier properties for repositories of radioactive and industrial wastes, especially in the case of dealing with liquid radioactive wastes. 
Acknowledgments: This work was financially supported by the Russian Science Foundation (Project \#16-17-10270). We thank Boris Pokid'ko for his help with analytical approach, and we also thank the "Bentonite" company for providing us with natural Bentonite clay from the Taganskoe deposit.

Author Contributions: Victoria V. Krupskaya prepared material, conceived and designed the experiments, and wrote the paper; Sergey V. Zakusin performed the experiments by $\mathrm{HNO}_{3}$ treatment and measured samples by X-ray diffraction and CEC; Ekaterina A. Tyupina analyzed specific surface area and porosity; Olga V. Dorzhieva collected data by infrared spectroscopy; Anatoliy P. Zhukhlistov studied samples by electron microscopy; Maria N. Timofeeva performed the experiments by $\mathrm{HCl}$ treatment acid treatment; and Petr E. Belousov prepared $<1 \mu \mathrm{m}$ fractions and measured CEC.

Conflicts of Interest: The authors declare no conflict of interest.

\section{References}

1. Pusch, R.; Knutsson, S.; Al-Taie, L.; Mohammed, M.H. Optimal ways of disposal of highly radioactive waste. Nat. Sci. 2012, 4, 906-918. [CrossRef]

2. Sellin, P.; Leupin, O.X. The use of clay as an engineered barrier in radioactive-waste management-A review. Clays Clay Miner. 2013, 61, 477-498. [CrossRef]

3. Laverov, N.P.; Velichkin, V.I.; Omelianenko, B.I.; Yudincev, S.V.; Petrov, V.A.; Bichkova, A.V. Part 5: Changes of the environment and climate. In Isolation of Spent Nuclear Materials: Geological and Geochemical Bases; IGEM RAS, IFZ RAS: Moscow, Russia, 2008; p. 280. (In Russian)

4. Drits, V.A.; Choubar, C. X-ray Diffraction by Disordered Lamelar Structure. X-ray Diffraction by Disordered Lamelar Structure; Springer-Verlag: Berlin/Heidelberg, Germany, 1990; p. 371.

5. Moore, D.M.; Reynolds, R.C., Jr. X-ray Diffraction and the Identification and Analysis of Clay Minerals, 2nd ed.; Oxford University Press: Oxford, UK, 1997; p. 378.

6. Guggenheim, S.; Adams, J.M.; Bain, D.C.; Bergaya, F.; Brigatti, M.F.; Drits, V.A.; Formoso, M.L.L.; Gala, N.E.; Kogure, T.; Stanjek, H. Summary of recommendations of nomenclature committees. Relevant to clay mineralogy: Report of the Association Internationale Pour L'etude des Argiles (AIPEA) Nomenclature Committee for 2006. Clays Clay Miner. 2006, 54, 761-772. [CrossRef]

7. Brindley, G.W.; Brown, G. (Eds.) Crystal Structures of Clay Minerals and Their X-ray Identification; Mineralogical Society: London, UK, 1980.

8. Wilson, M.J. Rock-Forming Minerals. Sheet Silikates: Clays Minerals; The Geological Society: London, UK, 2013; p. 724.

9. Laverov, N.P.; Yudintsev, S.V.; Kochkin, B.T.; Malkovsky, V.I. The Russian strategy of using crystalline rock as a repository for nuclear waste. Elements 2016, 12, 253-256. [CrossRef]

10. Gupalo, T.A.; Kudinov, K.G.; Jardine, L.J.; Williams, J. Development of a Comprehensive Plan for Scientific Research, Exploration, and Design: Creation of an Underground Radioactive Waste Isolation Facility at the Nizhnekansky Rock Massif. In Proceedings of the Waste Management 2005 Symposium, Tucson, AZ, USA, 27 February-3 March 2005.

11. Komadel, P. Chemically modified smectites. Clay Miner. 2003, 38, 127-138. [CrossRef]

12. Tomić, Z.P.; Antić Mladenović, S.B.; Babić, B.M.; Poharc Logar, V.A.; Đorđević, A.R.; Cupać, S.B. Modification of smectite structure by sulfuric acid and characteristics of the modified smectite. J. Agric. Sci. 2011, 56, 25-35.

13. Okada, K.; Arimitsu, N.; Kameshima, Y.; Nakajima, A.; MacKenzie, K.J.D. Solid acidity of 2:1 type clay minerals activated by selective leaching. Appl. Clay Sci. 2006, 31, 185-193. [CrossRef]

14. Kumar, P.; Jasra, R.V.; Bhat, T.S.G. Evolution of Porosity and Surface Acidity in Montmorillonite Clay on Acid Activation. Ind. Eng. Chem. Res. 1995, 34, 1440-1448. [CrossRef]

15. Komadel, P.; Madejova, J. Chapter 7.1: Acid activation of clay minerals. In Handbook of Clay Science; Developments in Clay Science; Bergaya, F., Theng, B.K.G., Lagaly, G., Eds.; Elsevier: Amsterdam, The Netherlands, 2006; Volume 1, p. 263287.

16. Carrado, K.A.; Komadel, P. Acid activation of bentonites and polymer-clay nanocompo-sites. Elements 2009, 5, 111-116. [CrossRef]

17. Dubikova, M.; Cambier, P.; Sucha, V.; Caplovicova, M. Experimental soil acidification. Appl. Geochem. 2002, 17, 245-257. [CrossRef] 
18. Pagano, T.; Sergio, M.; Glisenti, L.; Diano, W.; Grompone, M.A. Use of pillared montmorillonites to eliminate chlorophyll from rice bran oil. Ing. Quim. 2001, 19, 11-19.

19. Tyupina, E.A.; Magomedbekov, E.P.; Tuchkova, A.I.; Timerkaev, V.B. The sorption refinement of liquid organic radioactive waste for Cs-137. Adv. Mater. Spec. Issue 2010, 8, 329-333. (In Russian).

20. Vicente, M.A.; Suarez Barrios, M.; Lopez Gonzalez, J.D.; Banares Munoz, M.A. Characterization, surface area, and porosity analyses of the solids obtained by acid leaching of a saponite. Langmuir 1996, 12, 566-572. [CrossRef]

21. Komadel, P. Structure and chemical characteristics of modified clays. In Natural Microporous Materials in Environmental Technology; Misealides, P., Macasek, F., Pinnavaia, T.J., Colella, C., Eds.; Kluwer: Alphen aan den Rijn, The Netherlands, 1999; pp. 3-18.

22. Tkac, I.; Komadel, P.; Muller, D. Acid-treated Montmorillonites-A Study by 29Si and 27Al MAS NMR. Clay Miner. 1994, 29, 11-19. [CrossRef]

23. He, H.; Guo, J.; Xie, X.; Lin, H.; Li, L. A microstructural study of acid-activated montmorillonite from Choushan, China. Clay Miner. 2002, 37, 337-344. [CrossRef]

24. Timofeeva, M.N.; Panchenko, V.N.; Gil, A.; Zakusin, S.V.; Krupskaya, V.V.; Volcho, K.P.; Vicente, M.A. Effect of structure and acidity of acid modified clay materials on synthesis of octahydro-2H-chromen-4-ol from vanillin and isopulegol. Catal. Commun. 2015, 69, 234-238. [CrossRef]

25. Novikova, L.; Belchinskaya, L.; Krupskaya, V.; Roessner, F.; Zhabin, A. Effect of acid and alkaline treatment on physical-chemical properties of surface of natural glauconite. Sorpt. Chromatogr. Process. 2015, 15, 730-740.

26. Timofeeva, M.N.; Volcho, K.P.; Mikhalchenko, O.S.; Panchenko, V.N.; Krupskaya, V.V.; Tsybulya, S.V.; Gil, A.; Vicente, M.A.; Salakhutdinov, N.F. Synthesis of octahydro-2H-chromen-4-ol from vanillin and isopulegol over acid modified montmorillonite clays: Effect of acidity on the Prins cyclization. J. Mol. Catal. A Chem. 2015, 398, 26-34. [CrossRef]

27. Franco, F.; Pozo, M.; Cecilia, J.A.; Benítez-Guerrero, M.; Lorente, M. Effectiveness of microwave assisted acid treatment on dioctahedral and trioctahedral smectites. The influence of octahedral composition. Appl. Clay Sci. 2016, 120, 70-80. [CrossRef]

28. Adams, J.M. Synthetic organic chemistry using pillared, cation-exchanged and acid- treated montmorillonite catalysts-A review. Appl. Clay Sci. 1987, 2, 309-342. [CrossRef]

29. Brown, D.R. Review: Clays as catalyst and reagent support. Geol. Carpath. Ser. Clays 1994, 45, 45-56. [CrossRef]

30. Bovey, J.; Jones, W. Characterization of Al-pillared acid-activated clay catalysts. J. Mater. Chem. 1995, 5, 2027-2035. [CrossRef]

31. Timofeeva, M.N.; Panchenko, V.N.; Volcho, K.P.; Zakusin, S.V.; Krupskaya, V.V.; Gil, A.; Mikhalchenko, O.S.; Vicente, M.A. Effect of acid modification of kaolin and metakaolin on Brønsted acidity and catalytic properties in the synthesis of octahydro-2H-chromen-4-ol from vanillin and isopulegol. J. Mol. Catal. A Chem. 2016, 414, 160-166. [CrossRef]

32. Timofeeva, M.N.; Panchenko, V.N.; Krupskaya, V.V.; Gil, A.; Vicente, M.A. Effect of nitric acid modification of montmorillonite clay on synthesis of sotketal from glycerol and acetone. Catal. Commun. 2017, 90, 65-69. [CrossRef]

33. Tokarev, I.V.; Rumynin, V.G.; Zubkov, A.A.; Pozdnyakov, S.P.; Polyakov, V.A.; Kuznetsov, V.Y.U. Assessment of the long-term safety of radioactive waste disposal: 1 . Paleoreconstruction of groundwater formation conditions. Water Resour. 2009, 36, 206-213. [CrossRef]

34. Zubkov, A.A.; Balakhonov, B.G.; Sukhorukov, V.A.; Noskov, M.D.; Kessler, A.G.; Zhiganov, A.N.; Zakharova, E.V.; Darskaya, E.N.; Egorov, G.F.; Istomin, A.D. Radionuclide distribution in a sandstone injection zone in the course of acidic liquid radioactive waste disposal. Dev. Water Sci. 2005, 52, 491-500.

35. Rybalchenko, A.; Pimenov, M.; Kostin, P. Injection Disposal of Hazardous and Industrial Wastes, Scientific and Engineering Aspects. In Deep Injection Disposal of Liquid Radioactive Waste in Russia; Academic Press: New York, NY, USA, 1998; p. 780.

36. Rybalchenko, A.I.; Pimenov, M.K.; Kurochkin, V.M.; Kamnev, E.N.; Korotkevich, V.M.; Zubkov, A.A.; Khafizov, R.R. Deep Injection Disposal of Liquid Radioactive Waste in Russia. Dev. Water Sci. 2005, 52, 13-19.

37. Utkin, S.S.; Linge, I.I. Decommissioning strategy for liquid low-level radioactive waste surface storage water reservoir. J. Environ. Radioact. 2016. [CrossRef] [PubMed] 
38. Malkovsky, V.I.; Dikov, Y.P.; Asadulin, E.E.; Krupskaya, V.V. Influence of host rocks on composition of colloid particles in groundwater at the Karachai Lake site. Clay Miner. 2012, 47, 391-400. [CrossRef]

39. Post, J.E.; Bish, D.L. Rietveld refinement of crystal structures using powder X-ray diffraction data. Rev. Mineral. Geochem. 1989, 20, 277-308.

40. Doebelin, N.; Kleeberg, R. Profex: A graphical user interface for the Rietveld refinement program BGMN. J. Appl. Crystallogr. 2015, 48, 1573-1580. [CrossRef] [PubMed]

41. Czímerová, A.; Bujdák, J.; Dohrmann, R. Traditional and novel methods for estimating the layer charge of smectites. Appl. Clay Sci. 2006, 34, 2-13. [CrossRef]

42. Zakusin, S.V.; Krupskaya, V.; Dorzhieva, O.V.; Zhuhlistov, A.P.; Tyupina, E.A. Modification of the adsorption properties. Sorpt. Chromatogr. Processes 2015, 15, 280-289.

43. Fineevich, V.P.; Allert, N.A.; Karpova, T.R.; Dupliakin, V.K. Composite nanomaterials based on acid-activated montmorillonite. Russ. Chem. J. 2007, 4, 69-74. (In Russian)

44. Tyagi, B.; Chudasama, C.D.; Jasra, R.V. Determination of structural modification in acid activated montmorillonite clay by FT-IR spectroscopy. Spectrochim. Acta Part A 2006, 64, 273-278. [CrossRef] [PubMed]

45. Rhodes, C.N.; Brown, D.R. Catalytic activity of acid-treated montmorillonite in polar and nonpolar reaction media. Catal. Lett. 1994, 24, 285-291. [CrossRef]

46. Shlikov, V.G. X-ray Analysis of Mineral Composition of Fine-Grained Soil; GEOS: Moscow, Russia, 2006; p. 175. (In Russian)

47. Madejova, J.; Komadel, P. Baseline studies of The Clay Minerals Society Source Clays: Infrared methods. Clays Clay Miner. 2001, 49, 410-432. [CrossRef]

48. Russell, J.D.; Fraser, A.R. Clay Mineralogy: Spectroscopic and Chemical Determinative Methods; Wilson, M.J., Ed.; Chapman \& Hall: London, UK, 1996; pp. 11-67.

49. Pentrák, M.; Czímerová, A.; Madejová, J.; Komadel, P. Changes in layer charge of clay minerals upon acid treatment as obtained from their interactions with methylene blue. Appl. Clay Sci. 2012, 55, 100-107. [CrossRef]

50. Komadel, P. Acid activated clays: Materials in continuous demand. Appl. Clay Sci. 2016, 131, 84-99. [CrossRef]

51. Dong, H.; Peacor, D.R. TEM observations of coherent stacking relations in smectite, i/s and illite of shales: Evidence for Macewan crystallites and dominance of 2M1 polytypism. Clays Clay Miner. 1996, 44, 257-275. [CrossRef]

52. Osipov, V.I.; Sokolov, V.N. Clays and Its Properties. Composition, Structure and Properties Formation; GEOS: Moscow, Russia, 2013; p. 576. (In Russian)

53. Simc, V.; Uhlík, P. Crystallite size distribution of clay minerals from selected Serbian clay deposits. Geoloski Anali Balkanskoga Poluostrva 2006, 67, 109-116.

54. Kotarba, M.; Srodon, J. Diagenetic evolution of crystallite thickness distribution of illitic material in Carpathian shales, studied by the Bertaut-Warren-Averbach XRD method (MudMaster computer program). Clay Miner. 2000, 35, 383-391. [CrossRef]

55. Mystkowski, K.; Srodon, J. Mean thickness and thickness distribution of smectite crystallites. Clay Miner. 2000, 35, 545-557. [CrossRef]

56. Trofimov, V.T.; Korolev, V.A.; Voznesensky, E.A.; Golodovskaya, G.A.; Vasil'chuk, Y.K.; Ziangirov, R.S. Soil Science, 6th ed.; MSU: Moscow, Russia, 2005; p. 1024. (In Russian)

57. Rouquerolt, J.; Avnir, D.; Fairbridge, C.W.; Everett, D.H.; Haynes, J.H.; Pernicone, N.; Ramsay, J.D.F.; Sing, K.S.W.; Unger, K.K. Recommendations for the characterization of porous solids. Pure Appl. Chem. 1994, $66,1739-1758$.

58. Karnauhov, A.P. Adsorption. Texture of Dispersive and Porous Materials; Nauka: Novosibirsk, Russia, 1999; p. 470. (In Russian)

59. IUPAC. Manual of Symbols and Terminology. Pure Appl. Chem. 1972, 31, 577.

60. Churakov, S. Mobility of $\mathrm{Na}$ and $\mathrm{Cs}$ on Montmorillonite Surface under Partially Saturated Conditions. Environ. Sci. Technol. 2013, 47, 9816-9823. [CrossRef] [PubMed]

61. Thommes, M.; Kaneko, K.; Neimark, A.V.; Olivier, J.P.; Rodriguez-Reinoso, F.; Rouquerol, J.; Sing, K.S.W. Physisorption of gases, with special reference to the evaluation of surface area and pore size distribution (IUPAC Technical Report). Pure Appl. Chem. 2015, 87, 1051-1069. [CrossRef] 
62. Novikova, L.; Ayrault, P.; Fontaine, C.; Chatel, G.; Jérôme, F.; Belchinskaya, L. Effect of low frequency ultrasound on the surface properties of natural aluminosilicates. Ultrason. Sonochem. 2016, 31, 598-609. [CrossRef] [PubMed]

63. Kheok, S.C.; Lim, E.E. Mechanism of palm oil bleaching by montmorillonites clay activated at various acid concentrations. J. Am. Oil Chem. Soc. 1982, 59, 129-131. [CrossRef]

64. Morgan, D.A.; Shaw, D.B.; Sidebottom, T.C.; Soon, T.C.; Taylor, R.S. The function of bleaching earth in the processing of palm, palm kernel and coconut oils. J. Am. Oil Chem. Soc. 1985, 62, 292-299. [CrossRef]

(c) 2017 by the authors. Licensee MDPI, Basel, Switzerland. This article is an open access article distributed under the terms and conditions of the Creative Commons Attribution (CC BY) license (http:/ / creativecommons.org/licenses/by/4.0/). 